\title{
Shaping City Brand Ambassadoship Behavior Through City Green Resource Brand:
}

\author{
The Imperative Role of Residents in City Branding
}

\author{
Anni Rahimah* \\ Department of Business Administration \\ Universitas Brawijaya \\ Malang, Indonesia \\ *anni@ub.ac.id
}

\begin{abstract}
Applying self-congruity theory, this research investigates how city green resource brands influence residents' city ambassadorship behavior under the contingent condition of apathy. By employing cluster random sampling, research data were obtained from a sample of 266 residents of Surabaya, Indonesia. The findings disclose that city green resource brand building city image and ultimately, this image is found to escalate resident satisfaction and city brand attitude. Meanwhile, resident satisfaction reinforces the resident's attitude regarding their city; these two viewpoints are found to serve located precursors in intensify city brand ambassadorship behavior. It is also revealed that city image affects city brand ambassadorship action through the mediating variables of residential satisfaction and city brand attitude. The most exciting result was that apathy has been found invigorated city green resource brands' effect on city image. Gender, age, and stay duration act as control variables for the city ambassadorship behavior. Aside from the concept into the pathway of residents' city brand attitudes and behavior are shaped, this study offers a framework for public policymakers and city marketers intervention to meliorate the city green resources.
\end{abstract}

Keywords - city image, resident satisfaction, city brand attitude, apathy, self-congruity theory

\section{INTRODUCTION}

A city is not only as of the residence for a group of people, but it also serves as a marketable brand to attract non-residents to visit, travel, stay, and even invest. Therefore, city branding is growing become a topical issue as cities strive to distinguish themselves from others and create unique identities, particularly in the face of fierce global competition. Accordingly, the towns need resources to thrive, expand, and prosper. On another side, the program to intensify and amplify the city branding through comprehensive approaches (i.e., advertising and promotional campaigns, forums, fairs, investors' roadshows, and mega-events) requires a significant effort and money. It would be a challenge to design a stable city branding strategy.
To build a great brand of the city, the government administration should not only employ companies, visitors, and investors as the city's costumers, but also incorporate their city's residents. City branding focuses not only on attempting to make a city more appealing to visitors and investors, but also its emphasis on residents who have become the essential element. As a satisfied consumer can generate positive wordof-mouth reviews of a company that can influence other consumers [1], the residents can give a good recommendation regarding their city for a non-resident who seeks advice. Thus, the residents considered the city government's top priority to build an outstanding city branding that eases to reach low cost rather than enthrall attention from visitors and investors.

Braun et al. [2] has elaborate on three essential resident's roles in city branding. First of all, residents are the city branding subjects because the resident representatives are the decision-makers in city branding policy. Thus, the success of the city branding program relies on the residents itself. Second, residents should be a core element in city branding since today, as tourists visit a city, they recognize the city's external attributes and the lives of residents in deciding the importance of their visit. Ultimately, residents can serve as brand ambassadors for their city. These residents' prominent roles make the administrator understand their own residents' attitudes and behavior toward their city.

Recently, the academics have studied the issue of residents' behavior, such as the psychological benefits of city residents [3], resident attitude toward tourism [4], or resident city identification [5]. Another study claims that the residents are the potential co-designer of the city brand [2]. Thus, the residents could act as participatory co-creators of the city architecture for multiplying the public services and attract the visitor to visit and invest in their city.

Despite the imperative role of the resident in city branding, however, there is a shortage of research elaborating on the residents' behavior as the city ambassador. Furthermore, understanding the dynamic factors that can stimulate ambassadorship behavior cannot be overlooked. Scholars have 
mostly drawn on residents' perception toward the city to build their understanding of the process of building ambassadorship behavior among residents. Despite that, residents' perception requires a reason as the foundation to willingly conduct a specific attitude and behavior.

Bearing in mind the promising avenue of research for such a phenomenon, this study purposes to extend the understanding of city residents' attitudes and behavior toward their city, especially as the city ambassador. City ambassadorship behavior is a relatively new concept in the arena of city branding. This behavior of the resident can enhance the strong city branding as residents will deliver accurate and positive information about their city to prospective investors or visitors. This behavior is the result of the city brand attitude promoted by city image and residents' satisfaction. All these consumers' perspective toward their city could be built by the green resources that provided by the city government.

By addressing the research void, this study contributes to the city branding literature by employing city green brand resources, hereinafter (CGRB), the unexplored determinants, as the underpinning principles to justify the city ambassadorship behavior. Drawing on the self-congruity theory, a bolster work in city branding proposes and examines a four-stage, theoretically grounded framework rooted in city ambassadorship behavior. The mediating mechanisms predominantly formed by relationships detail the intervening processes and advance residents' perspective toward their own city knowledge. In this regard, this research provides evidence of the applicability of the self-congruity theory in the studied city green resource brand and city ambassadorship behavior context. This research is a pioneer work that attempts to investigate the contingent of apathy that sharpens the comprehension and presents insight into city branding's proposed mechanisms. The paper goes further by employs several city branding instructions with empirical supports are elicited for city branding policymakers and city marketers according to the findings.

\section{LITERATURE OF REVIEW}

The presumed citizen within their city representation is a crucial concern in the context of the socio-cultural intricacy [6]. City services build residents' impression that can affect related attitudes among inhabitants in communities. It can also be expected that a presumed correspondence between the residents' personality and the city's identity will result in favorable attitudes and actions towards the city's brand. Current research uses this theoretical underpinning, known as the principle of self-congruity, in several ways: (a) to conceptualize the impact of CGRB on the city image among residents; (b) to investigate the effect of the city's image on the residents' satisfaction, attitude, and behavior, especially the city ambassadorship behavior.

Scholars have advocated the successful employment of city green spaces or resources in branding of a certain city to make cities more desirable, sustainable and eventually competitive.
In this research, city green resources are determined as a visible, accessible, available green sites or green spaces in a city [7]. These ecological resources comprise the parks around the city for public and other green areas, mini zoo, trees, and landscapes. Green resources offer an experience to embrace the natural atmosphere and help build a city image that magnify cities' attractiveness, incorporating the perceptions and expectations of city residents. This lead to the examined hypothesis below:

\section{H1: The higher CGRB is, the higher the city image.}

The apathy on an environmental issue may emerge among the city residents for some reasons. The lack of information, the growing of an instant generation that urge to get what they want easily and instantly or irresponsible behavior. In such condition, the apathic residents may think that the problem of natural resource depletion is exaggerated topic, hard to get concerned on an ecological issue, or even opposed the environmental conservation. Thereby, the apathy may enervate the effect of green resources that provide by the city government toward an interesting image of their city. Accordingly, the current study hypothesizes that:

\section{H2: Apathy weakens the effect of CGRB on city image.}

The image of brand is conceptualized as the perceptions toward a particular brand that delineated as the existing of associations in the consumers' memory [8], which is a crucial part of powerful brands. Much attention to the study of destination or a specific place image primarily lies in the latter influence on consumers' behaviors. Empirical evidence supports the notion that the destination image is a key factor likely to have a significant impact on the decision-making process of visitors [9]. Moreover, the image of a city influences city consumers' choice processes and evaluates that destination and future intentions [10]. Resident satisfaction is a concrete and key success measure for city marketing [11]. The satisfaction's definition, which has been extensively discussed in the conventional marketing discipline, determined as "the emotional or dramatic response of the consumer to the perceived discrepancy between performance evaluation and expectations [12]. Thus, in this current study, resident satisfaction is conceptualized as an evaluative description of the perception of the use of the city service, based on the disparity between the previous expectation and the real results perceived after consumption. As city brands mitigate perceived risks that indicate high quality of brand, they can satisfy the functional and emotional needs of consumers. Further, Chon [13] claims that the position and effect of city image on the satisfaction of city consumers are the most common themes arising from the image of a location research. The pleasant image of the city, embedded in the minds of the residents, could develop the attitude of the residents, including the pride of living in the city and of assessing it as a reputable city. Given the above arguments and related literature, the following hypotheses associated with the effects of city image are proposed: 
H3: The higher the city image is, the higher resident satisfaction.

H4: The higher the city image is, the higher the city brand attitude.

Ambassadorship behavior is described as the positive wordof-mouth behavior of residents who promote the city to others [2], especially to non-resident. The positive word-of-mouth consists of informal communication through direct and online exchanges between a customer and others concerning evaluations of goods and services. This current study determines city ambassadorship behaviors as the residents' behavior who publicly supports the city through positive wordof-mouth communications and recommendations [14]. Previous marketing literature has identified satisfaction as notable attitudinal constructs that positively affect the positive attitude, such as pride and preference toward their city. Thus, the city must have a good connection with their residents in order to raise and maintain positive word-of-mouth communications, recommendations, or ambassadorship behavior among residents. Further, the result of this kind of resident positive attitude is positive word-of-mouth behaviors of residents [12]. Accordingly, the entire branding process's goal is to evoke and reinforce this positive word-of-mouth of behavior [15]. Taken together, when city brands are successful at satisfying residents' needs, the city resident develop a strong positive attitude and behavior toward their city. The city ambassadorship behavior enhances city brand communication because the actions are perceived as genuine and trustworthy. The above discussions lead to the following hypotheses:
H5: The higher the resident satisfaction is, the higher the city brand attitude.

H6: The higher the resident satisfaction is, the higher the city ambassadorship behavior

H7: The higher the city brand attitude is, the higher the city ambassadorship behavior.

Seminal research on city branding focuses mainly on community brand images. Phillips and Jang [16] examined how the destination image was linked to the tourist attitude as a determinant of behavioral intentions and confirmed that the destination image clarified the tourist attitude towards the destination. Bigne et al. [10] studied the interrelationships between the destination image, perceived quality, satisfaction, intention to return, and recommend other consumers willingly in the form of resort visitors. Their research found that the city image had an indirect impact on the inclination to propose others through satisfaction. A positive city brand image (i.e., positive perception among residents) is the most intense and consequential residents perceived in a marketing arena. It encourages residents' behavior through their evaluation and attitude towards the city. Relying on these syntheses, the following mediating hypotheses are developed:

H8: The resident satisfaction mediates the relationship between city image and city ambassadorship behavior

H9: The city brand attitude mediates the relationship between city image and city ambassadorship behavior.

These all hypotheses are illustrated on the research framework, as shown in Figure 1.

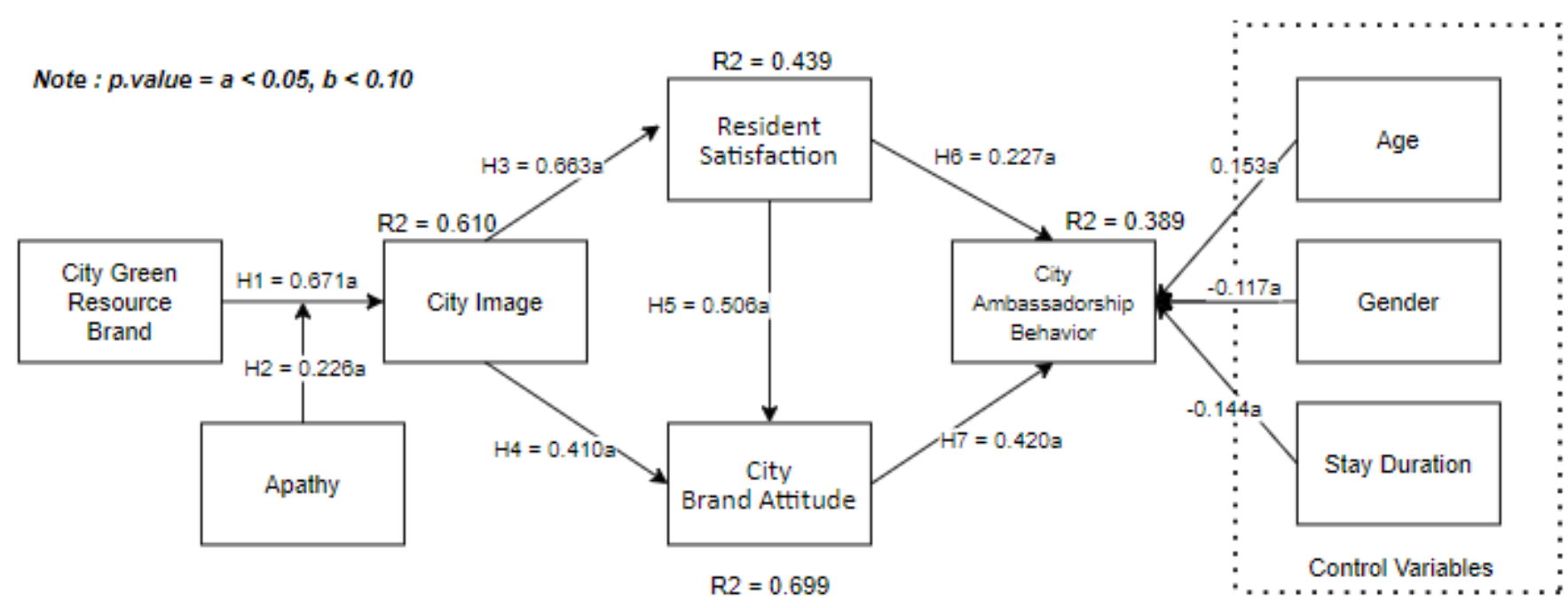

Fig. 1. The research framework, related hypotheses, and analysis results. 


\section{RESEARCH METHODOLOGY}

\section{A. Measurements Scale}

Initially, validated scales were adapted to fit the current research context of city ambassadorship behavior. A sevenpoint Likert metric was applied for the scales. The complete list of measurement items is presented in Appendix 1. The CGRB and city image scales, the two of the second-order constructs in the research model, were derived from Chan and Marafa [17] and Hosany et al. [18] respectively. CGRB consisted of six dimensions (i.e., green status, green space, green potential, green pulse, green citizenship, and green infrastructure), while the city image has the affective, physical atmosphere, and accessibility dimensions. Among the studied constructs from the resident perspective, the measure of resident satisfaction was borrowed from Taecharungroj [14] three-item scale, while the operationalization of city brand attitude was adopted from Merrilees et al. [19]. The scales of city ambassadorship behavior as the final outcome variable were assessed by the well-established three-item of Taecharungroj [14]. Finally, as a moderating variable, apathy was investigated by a seven-item index drawn from the study of Bonnes et al. [20]. Further, demographic factors (i.e., age, gender, and stay duration) were included as control variables in the research model, while they were measured using a single-item categorical scale.

As all the scale items originally came from English literature and Indonesia is a non-English speaking country, a back-translation approach was conducted by two independent scholars who are bilingual and competent in the subject matter. A pre-test was then conducted with 30 respondents to ensure the questionnaire's qualified content before the mass collection of the data. Changes were made to improve the wordings and format of the questionnaire accordingly.

\section{B. Research Setting and Data Collection}

The field research was conducted with consumers in Surabaya of Indonesia. Surabaya is the second-largest city in Indonesia and the centre of modernity in Eastern Indonesia. Recently, Surabaya has received the Sustainable City and Human Settlements Award (SCAHSA) award for the Global Green City category in the United Nations environmental program event in New York, US. This city has been chosen because it meets the requirements of Global Green City, which is focused on the environmental effect, ecological balance, and sustainable growth. Surabaya has implemented a sustainable urban planning system. It sets out numerous local regulations related to the provision of Green Open Space (RTH), public services and utilities, as well as waste management facilities. These regional regulations are defined in order to protect the environment from the adverse effects of development.

Since the population is spread over a large geographical area and divided into clusters, a random sample of clusters is selected. As the population is distributed over a wide geographic region and separated into clusters, a random sampling of clusters is chosen. A cluster-based on the five Surabaya district was employed. Further, a random sample of units is selected from the selected clusters. To ensure an approximate representation of the respective population., the survey questionnaire was distributed in green space in five districts chosen from 143 cities green space in Surabaya. Two filtering questions were used to identify eligible respondents, including Surabaya residents and over 17 years old. Finally, 266 valid questionnaires were collected and used for the subsequent data analysis. The demographic characteristics of the participants are shown in Table I.

TABLE I. SAMPLE DEMOGRAPHIC CHARACTERISTICS

\begin{tabular}{|c|c|c|c|c|c|}
\hline Gender & Freq. & $\%$ & $\begin{array}{l}\text { Monthly income } \\
\text { (IDR)* }\end{array}$ & Freq. & $\%$ \\
\hline Male & 124 & 46.6 & $\leq \mathrm{Rp} 1.5 \mathrm{~m}$ & 122 & 20.0 \\
\hline Female & 142 & 53.4 & $\mathrm{Rp} 1.5 \mathrm{~m}-3 \mathrm{~m}$ & 49 & 17.1 \\
\hline Total & 266 & 100.0 & $>\mathrm{Rp} 3 \mathrm{~m}-4 \mathrm{~m}$ & 57 & 25.2 \\
\hline Age & Freq. & $\%$ & $>\mathrm{Rp} 4 \mathrm{~m}$ & 38 & 37.6 \\
\hline $17-26$ & 152 & 57.1 & Total & 266 & 100.0 \\
\hline $27-36$ & 55 & 20.7 & Stay Duration & Freq. & $\%$ \\
\hline $37-46$ & 39 & 14.7 & $0-5$ years & 6 & 2.3 \\
\hline$\geq 50$ & 20 & 7.5 & $6-10$ years & 5 & 1.9 \\
\hline Total & 266 & 100.0 & 11-15 years & 18 & 6.8 \\
\hline Education & Freq. & $\%$ & 16-20 years & 67 & 25.1 \\
\hline $\begin{array}{l}\text { Junior high } \\
\text { and below }\end{array}$ & 8 & 3.0 & $\begin{array}{l}\text { More than } 20 \\
\text { years }\end{array}$ & 170 & 63.9 \\
\hline $\begin{array}{l}\text { Senior high } \\
\text { school }\end{array}$ & 150 & 56.4 & Total & 266 & 100.0 \\
\hline $\begin{array}{l}\text { College or } \\
\text { university }\end{array}$ & 100 & 37.6 & \multirow{3}{*}{\multicolumn{3}{|c|}{$\begin{array}{l}\text { **Indonesian Rupiah, } \\
\text { exchange rate at: } \\
\text { RP } 1,000 \text { to USD } 0.074\end{array}$}} \\
\hline $\begin{array}{l}\text { Post } \\
\text { graduate } \\
\text { and above }\end{array}$ & 8 & 3.0 & & & \\
\hline Total & 266 & 100.0 & & & \\
\hline
\end{tabular}

\section{RESULTS}

The Partial Least Square (PLS) analysis with standard bootstrapping using SmartPLS 3.2.8 software [21] was applied to evaluate the measurements in addition to the direct and moderating effects of the proposed framework.

\section{A. Common Method Bias}

Common method bias (CMB) is deemed to occur due to self-reported data, causing erroneous data analyses and distorting the subsequent research findings' following interpretation. In this regard, according to Wilden and Gudergan [22], when conducting research models with moderators, survey respondents are unlikely to predict or manipulate their responses to the moderation effects. In this research, since apathy was included as a moderator, a serious concern regarding $\mathrm{CMB}$ can be released. Further, to bolster the argument that $\mathrm{CMB}$ was not a significant concern in this framework, two standard statistical tests were performed. First, Harman's single-factor test was carried out; the scale items of all theoretical constructs were pooled into a principlecomponent factor-analysis without rotation. The findings indicated that no single factor accounted for more than $43 \%$ of the variance, which was below the $50 \%$ threshold set by Podsakoff and Orgn [23]. Then, a common method-factor was supplemented to estimate the loadings on every item in the 
research model. This research used seven goodness-of-fit statistics for model evaluation (i.e., the chi-square statistic, CMINDF, RMSEA, GFI, AGFI, TLI, and also CFI). The results of the goodness of fit demonstrated that all the values did not exceed the threshold. Based on those subsequent tests, it was confirmed that CMB was not a problem with this study's findings.

\section{B. Model Fit}

In order to determine the overall model-fit of the proposed framework, standardised root mean squared residuals (SRMR), structural variance inflation factor (VIF) coefficients, explanatory power $\left(R^{2}\right)$, and predictive relevance $\left(Q^{2}\right)$ were examined. The value of SRMR was calculated to be 0.074 , which reached the threshold of 0.08 [24]. All inner VIF values were between $1.000-2.613$ below the threshold of 3.3 [25]. All $R^{2}$ values which ranged from 0.389-0.699, satisfied the minimum value of 10\% [26] (Falk and Miller, 1992), thereby indicating the sufficient explanatory power and satisfactory predictive relevance of the exogenous latent variables. Finally, the Stone-Geisser Indicator $\left(Q^{2}\right)$ values were between $0.389-$ 0.999 , all above the required value of zero [27]. All of these ensured a good model fit of the research framework.

\section{Measurement Accuracy Assessment}

The current research had four unidimensional constructs and two reflective-reflective second-order constructs. Due to the inclusion of two second-order constructs in the studied framework, a two-step approach method in PLS was applied
[28]. All variables, including the unidimensional constructs and the second-order construct, were initially included in the model to obtain the latent variable scores as well as to assess the scale accuracy of the unidimensional constructs and the lower-order dimensions of the second-order construct. The latent variable scores of these lower-order dimensions were then deployed as indicators for their higher-order construct. At the same time, the accuracy-test for the higher-order construct was further conducted.

The desirable psychometric properties of the measurement model involved the assessment of internal consistency/reliability, convergent validity, and discriminant validity. The construct validity and reliability are shown in Table II; meanwhile, the accuracy analysis results are printed in Tables III and IV. All the remained measurement items exhibited satisfactory psychometric properties. Firstly, internal consistency/reliability was assessed using Cronbach's alpha $(\alpha)$ and composite reliabilities (CR), while the calculated values all exceeded thresholds of 0.7 . Then, all studied constructs' convergent validity was also established because average variance extracted (AVE) values were above the stipulated levels of 0.5 , and item-loadings on their corresponding constructs were higher than the cross-loadings on other studied constructs. Finally, the scales exhibited ample discriminant validity because the square-roots of AVE values were all greater than the highest shared variances $(\mathrm{SVs})$ or the bivariate correlations between the constructs of interest with other constructs.

TABLE II. CONSTRUCT VALIDITY AND RELIABILITY

\begin{tabular}{|c|c|c|c|c|c|c|c|c|c|}
\hline \multirow{4}{*}{ Research Variables } & & & & & & & Total effects & & \\
\hline & \multicolumn{6}{|c|}{ Mediators } & Final outcomes & & \\
\hline & \multicolumn{2}{|l|}{ DI } & \multicolumn{2}{|l|}{ RSS } & \multicolumn{2}{|l|}{ CBA } & $\mathrm{CAB}$ & & \\
\hline & Direct & Total & Direct & Total & Direct & Total & Direct & Indirect & Total \\
\hline \multicolumn{10}{|c|}{ Drivers (independent variables) } \\
\hline CGR & 0.671 & 0.671 & & & & & & & \\
\hline \multicolumn{10}{|c|}{ Mediators } \\
\hline DI & & & 0.663 & 0.663 & 0.410 & 0.410 & & 0.491 & 0.491 \\
\hline RSS & & & & & 0.506 & 0.506 & 0.227 & 0.213 & 0.440 \\
\hline CBA & & & & & & & 0.420 & & 0.420 \\
\hline
\end{tabular}

TABLE III. SCALE ACCURACY ANALYSIS

\begin{tabular}{|c|c|c|c|c|c|c|c|}
\hline \multirow{2}{*}{\multicolumn{2}{|c|}{$\begin{array}{l}\text { Hierarchical measurement model } \\
\text { Studied constructs (Dimensions) }\end{array}$}} & \multicolumn{2}{|c|}{ no of scale items ${ }^{\mathrm{a}}$} & \multirow[t]{2}{*}{ alpha } & \multirow[t]{2}{*}{$\mathbf{C R}^{\mathrm{b}}$} & \multirow[t]{2}{*}{$\mathbf{A V E ^ { \mathbf { c } }}$} & \multirow[t]{2}{*}{ Item loading } \\
\hline & & Original & Final & & & & \\
\hline \multicolumn{2}{|c|}{ City Ambasadorship Behavior } & 2 & 2 & 0.812 & 0.914 & 0.842 & $0.913-0.922$ \\
\hline \multicolumn{2}{|c|}{ City Brand Attitude } & 4 & 4 & 0.844 & 0.895 & 0.681 & $0.792-0.862$ \\
\hline \multirow{6}{*}{$\begin{array}{c}\text { City Green } \\
\text { Resource Brand }\end{array}$} & GSt & 5 & 5 & 0.848 & 0.897 & 0.623 & $0.728-0.860$ \\
\hline & $G S p$ & 3 & 3 & 0.767 & 0.866 & 0.683 & $0.797-0.850$ \\
\hline & GPo & 4 & 4 & 0.752 & 0.835 & 0.561 & $0.623-0.806$ \\
\hline & $G P u$ & 4 & 4 & 0.797 & 0.868 & 0.624 & $0.664-0.853$ \\
\hline & $G C i$ & 4 & 3 & 0.843 & 0.895 & 0.681 & $0.751-0.851$ \\
\hline & Gln & 3 & 3 & 0.827 & 0.897 & 0.744 & $0.826-0.886$ \\
\hline \multirow[t]{3}{*}{ City Image } & Aff & 4 & 4 & 0.826 & 0.896 & 0.742 & $0.819-0.912$ \\
\hline & $P A$ & 4 & 4 & 0.856 & 0.903 & 0.701 & \\
\hline & Acc & 4 & 4 & 0.805 & 0.873 & 0.636 & $0.650-0.861$ \\
\hline \multicolumn{2}{|c|}{ Resident Satisfaction } & 3 & 3 & 0.789 & 0.876 & 0.704 & $0.738-0.907$ \\
\hline
\end{tabular}


TABLE IV. SCALE ACCURACY ANALYSIS: DISCRIMINANT VALIDITY ASSESSMENT

\begin{tabular}{|c|c|c|c|c|c|c|c|c|c|c|c|c|}
\hline \multirow{2}{*}{$\begin{array}{l}\text { Studied constructs } \\
\text { (dimensions) }\end{array}$} & \multirow[t]{2}{*}{ CAB } & \multirow{2}{*}{$\begin{array}{c}\text { CB } \\
\mathbf{A}\end{array}$} & \multicolumn{6}{|c|}{ CGRB } & \multicolumn{3}{|c|}{ DI } & \multirow[t]{2}{*}{$\mathbf{R S}$} \\
\hline & & & $G C i$ & GP0 & $G P u$ & $G S p$ & Gst & Gln & $A c c$ & $\overline{A f f}$ & $P A$ & \\
\hline City Ambasadorship Behavior & 0.918 & & & & & & & & & & & \\
\hline City Brand Attitude & 0.569 & 0.825 & & & & & & & & & & \\
\hline City Green Resource Brand & 0.551 & 0.671 & 0.822 & & & & & & & & & \\
\hline GCi & 0.491 & 0.853 & 0.825 & & & & & & & & & \\
\hline GP0 & 0.484 & 0.578 & 0.480 & 0.749 & & & & & & & & \\
\hline GPu & 0.504 & 0.567 & 0.655 & 0.508 & 0.790 & & & & & & & \\
\hline GSp & 0.502 & 0.650 & 0.658 & 0.535 & 0.768 & 0.826 & & & & & & \\
\hline Gst & 0.417 & 0.610 & 0.594 & 0.466 & 0.651 & 0.712 & 0.789 & & & & & \\
\hline Gln & 0.527 & 0.628 & 0.649 & 0.527 & 0.753 & 0.717 & 0.594 & 0.862 & & & & \\
\hline City Image & 0.603 & 0.745 & 0.723 & 0.522 & 0.669 & 0.697 & 0.611 & 0.637 & 0.862 & & & \\
\hline Acc & 0.543 & 0.663 & 0.69 & 0.555 & 0.642 & 0.692 & 0.567 & 0.68 & 0.797 & & & \\
\hline Aff & 0.548 & 0.741 & 0.667 & 0.454 & 0.634 & 0.682 & 0.67 & 0.597 & 0.723 & 0.874 & & \\
\hline PA & 0.545 & 0.650 & 0.639 & 0.438 & 0.566 & 0.567 & 0.489 & 0.533 & 0.674 & 0.746 & 0.837 & \\
\hline Resident Satisfaction & 0.506 & 0.778 & 0.516 & 0.510 & 0.494 & 0.606 & 0.560 & 0.539 & 0.585 & 0.714 & 0.537 & 0.839 \\
\hline
\end{tabular}

\section{Structural Model And Hypotheses Assessment}

The test results support all direct hypotheses. CGRB was found to positively impact the city image (H1: 0.671, p <0.05). Furthermore, the analysis results also prove that city image has a significant positive effect on resident satisfaction (H3: 0.663 , $\mathrm{p}<0.05)$ and city brand attitude (H4: 0.410, p <0.05). City brand attitude is also affected by resident satisfaction significantly and positively by 0.506 (H5: 0.506, p <0.05). For city ambassadorship behavior, it is influenced significantly positively by resident satisfaction (H6: $0.227, \mathrm{p}<0.05)$ and city brand attitude (H7: $0.420, \mathrm{p}<0.05)$. Moreover, city ambassadorship behavior is also indirectly influenced by the city image through resident satisfaction $(\mathrm{H} 8: 0.151, \mathrm{p}<0.05)$ and city brand attitude (H9: 0.172, $\mathrm{p}<0.05)$.

To test the proposed moderating effect $(\mathrm{H} 2)$, the t-values and $f 2$ values were adopted to test the moderation coefficient's statistical significance and magnitude, respectively. The results presented in Figure 1 show that apathy moderates the effect of CGRB on city image with an error rate of $5 \%(\mathrm{H} 2: 0.226$, p $<0.10$ ), which indicates that apathy increases the impact of CGRB on city image. This result does not support the initial hypothesis, which states that apathy is weakened the influence of the CGRB on the city image. Among the control variables, age but not gender and stay duration significantly impacted the final outcome variables at a $95 \%$ confidence level.

\section{CONCLUSION AND DISCUSSION}

The issue of city branding has taken a centre stage in today's society. By employing the self-congruity theory, this research explores the implications of CGRB in the residents' attitudes and behavior toward their city. The finding reveals that CGRB has a positive relationship with the city image, whereas the residents' apathy, astonishingly at odds with the hypothesized direction, invigorates the effect. In addition, the city image is found to play a significant role in increasing residents' satisfaction towards the city services and escalating the city brand attitude amongst residents. The resident who satisfies with their city has a substantial effect on the positive city brand attitude. Further, resident satisfaction and city brand attitude build the city ambassadorship behavior. Therefore, the results provide evidence of the city image's predictive power in city ambassadorship behavior through the intervening mechanism of residents' satisfaction and city brand attitude.

Contrasting arguments often tend to emerge when individuals are asked to describe their relationship to urban city green spaces [20]. On the one hand, a general appreciation for these areas is usually expressed by respondents. People often refer to positive experiences within these areas, based on the possibility of closer sensorial contact with nature and relaxed social interactions with others. Urban green areas, on the other hand, can also cause negative reactions and considerations. When the city's green area has not been properly managed by the municipal authority and has not been adequately prepared for the needs of the residents inside the city and is not accessible for the public, this tends to drive to negative emotions and dissatisfaction with these sites. It thus seems that variations in views and assessments of urban green areas may be predicted for people who have different general definitions of human-nature relationships, and/or for people who favor conservative versus biospheric values.

\section{A. Theoretical Implications}

This research contributes to the extant literature in several ways. First, the research proposes a fresh standpoint to understand city ambassadorship behavior from the perspective of green city resources. Although studies on the application of the self-congruity theory are gaining ground in consumer behavior studies (e.g., Sirgy [29]; Islam et al. [30]), its application in the city's realm ambassadorship behavior that driven by green city resources is limited at best. In light of this, the current research advances the theory on residents' behavior toward their city by employing city green space. Similarly, the findings add to the limited research on residents' apathy. Second, this research adds to the stream of research on city branding through the city green resources and specifically to studying the driving forces of city ambassadorship behavior. In light of the redundancy of the brand ambassador behavior models, the current research provides a unique perspective by looking at the vital aspect of why the residents willingly act as 
the city ambassadorship for free by giving positive word-ofmouth to their relatives and friends.

\section{B. Managerial Implication}

This paper's study analysis results offer an indicative city brand framework for destination marketers and policymakers whose cities enjoy attractive green resources. Identifying the determinants of city brand ambassadorship affords a deeper understanding of how branding works in this particular context and provides a framework by which local governments can manage and modify such attitudes for the public good. The green city resources provide useful references for city brand management by understanding essential green space attributes and structures by residents and visitors. Based on the research finding, the city brand management should consider consumeroriented branding. Finally, the results are also very beneficial because they provide an opportunity for regional green brand development to form the city ambassadorship behavior among residents.

\section{Limitations}

Despite these critical contributions, this study has drawbacks that offer opportunities for future studies. The research data are based on self-reports and often reflect a reasonably accurate estimate of potential actions [31]. However, the views of residents with apathy are generally recorded as contrary to reality. Future studies should also consider the future effect of apathy against environmental concerns on urban consumers. Qualitative analysis, along with quantitative approaches, will resolve the tendency of apathy among residents in exploring the relationship between city brands. Moreover, given the diversity of green spaces between cities in Indonesia, the present study may not sufficiently capture regional variations. This phenomenon calls for vigilance when projecting results around Indonesia and provides a framework for examining city ambassadors' actions among people of other cities. This calls for caution when projecting results around Indonesia and provides a framework for reviewing city ambassadors' behavior among people of other cities. This also means that the results could not be extrapolated to other regions' situations due to the lack of numerous green spaces in a particular field. Future exploration across areas is also welcomed. Seeing variations between regions will also suggest the need for comparative studies and examine residents' perspectives on their cities.

\section{REFERENCES}

[1] E. Yu, J. Kim, "The relationship between self-city brand connection, city brand experience, and city brand ambassadors" Sustainability, vol. 12 no. 3, p. 982, 2020.

[2] E. Braun, M. Kavaratzis, M, and and S. Zenker, "My city-my brand: The different roles of residents in place branding", Journal of Place Management and Development, vol. 6 no. 1, pp. 18-28., 2013.

[3] K.J.H. Williams, K.E. Lee, L. Sargent, K.A. Johnson, J. Rayner, C. Farrell, R.E. Miller, N.S.G. Williams, "Appraising the psychological benefits of green roofs for city residents and workers," Urban Forestry \& Urban Greening, vol. 44, 126399, 2019.

[4] S. Wang, "Roles of place identity distinctiveness and continuity on resident attitude toward tourism," European Journal of Tourism Research, vol. 13, pp. 58-68, 2016.

[5] K.U. Mišič and K. Podnar, "The role of resident-city identification in building residents' city commitment," European Planning Studies, vol. 27 no. 7, pp. 1329-1349, 2019

[6] M.K. Ruzzier and N. Petek, "The importance of diverse stakeholders in place branding: The case of "I feel Slovenia", Anatolia: An International Journal of Tourism and Hospitality Research, vol. 23 no. 1, pp. 49-60, 2012.

[7] C.-S. Chan, and L.M. Marafa, "The green branding of Hong Kong visitors' and residents' perceptions", Journal of Place Management and Development, Vol. 9 no. 3, pp. 289-312, 2016.

[8] K.L. Keller, "Conceptualising, measuring and managing customer-based brand equity", Journal of Marketing, vol. 57, pp. 1-22, 1993.

[9] K.K. Byon and J.J. Zhang, "Development of a scale measuring destination image," Marketing Intelligence \& Planning, vol. 28 no. 4 , pp.508-532, 2010 .

[10] J. Bigne, M. Sanchez, and J. Sanchez, "Tourism image, evaluation variables and after purchase behavior: Inter-relationships", Tourism Management, vol. 22 no. 6, pp. 607-616, 2001.

[11] P. Goovaerts, H.V. Biesbroeck, and T.V. Tilt, "Measuring the effect and efficiency of city marketing", Procedia Economics and Finance, vol. 12, pp. 191-198, 2014.

[12] T. Hennig-Thurau, K.P. Gwinner, and D.D. Gremler, "Understanding relationship marketing outcomes: an integration of relational benefits and relationship quality", vol. 4 no. 3, pp. 230-347, 2002

[13] K. Chon, "The role of destination image in tourism: A review and discussion", The Tourist Review, vol. 45 no. 2, pp. 2-9, 1990.

[14] V. Taecharungroj, "City ambassadorship and citizenship behaviours: Modelling resident behaviours that help cities grow", Journal of Place Management and Development, vol. 9 no. 3, pp. 331-350, 2016.

[15] M. Kavaratzis, "From city marketing to city branding: Towards a theoretical framework for developing city brands", Place Branding, vol. 1 no. 1, pp. 58- 73, 2004.

[16] W. Phillips and S. Jang, "Destination image and tourist attitude", Tourism Analysis, vol. 13, pp. 401-411, 2008.

[17] C. Chan and L.M. Marafa, "Rebranding Hong Kong "Green": The potential for connecting city branding with green resources," World Leisure Journal, vol. 56 no. 1, pp. 62-80, 2014.

[18] S. Hosany, Y. Ekinci, and M. Uysal, "Destination image and destination personality," International Journal of Culture, Tourism and Hospitality Research, vol. 1 no. 1, pp. 62-81, 2007.

[19] B. Merrilees, D. Miller, and C. Herington, "Antecedents of residents: city brand attitudes," City Brand, vol. 62 no. 3, pp. 363-364, 2009

[20] M. Bonnes, P. Passafaro, and G. Carrus, "The ambivalence of attitudes toward urban greenareas: between proenvironmental worldviews and daily residential experience," Environmentand Behavior, vol. 43 no. 2, pp. 207-232, 2011.

[21] C. Ringle, S. Wende, and J.M. Becker, SmartPLS 3, Bönningstedt, Germany, available at: smartpls.com, 2015.

[22] R. Wilden and S.P. Gudergan, "The impact of dynamic capabilities on operational marketing and technological capabilities: Investigating the role of environmental turbulence. Journal of the Academy of Marketing Science, vol. 43 no. 2, pp. 181-199, 2015.

[23] P.M. Podsakoff and D.W. Organ, "Self-reports in organizational research: Problems and prospects," Journal of Management, vol. 12 no. 4, pp. 531-544, 1986.

[24] J. Henseler, T.K. Dijkstra, M. Sarstedt, C.M. Ringle, A. Diamantopoulos, D.W. Straub, D.J.Jr. Ketchen, J.F. Hair, G.T.M. Hult, and R.J. Calantone, "Common beliefs and reality about PLS: Comments 
on Rönkkö and Evermann (2013)". Organizational Research Methods, vol. 17 no. 2, pp. 182-209, 2014

[25] J.F. Hair, G.T.M. Hult, C. Ringle, and M. Sarsted, "A primer on partial least squares structural equation modeling (PLS-SEM). Thousand Oaks, CA, USA: Sage Publications, 2016.

[26] R.F. Falk and N.B. Miller, A Primer for Soft Modeling, University of Akron Press, Akron, OH, USA, 1992.

[27] J. Henseler, C.M Ringle, and R.R. Sinkovics (2009), "The use of partial least squares path modeling in international marketing", In Sinkovics, R. $\mathrm{R}$ and Ghauri, P. N. (eds.), New Challenges to International Marketing (Advances in International Marketing, Volume 20), Bingley, England, UK: Emerald Publishing, pp. 277-319.
[28] J.M. Becker, K. Klein, and M. Wetzels, M, "Hierarchical latent variable models in PLS-SEM: Guidelines for using reflective-formative type models," Long Range Planning, vol. 45 no.5-6, pp. 359-394, 2012.

[29] M.J. Sirgy, "Self-congruity theory in consumer behavior: A little history, Journal of Global Scholars of Marketing Science, vol. 28 no. 2, pp. 197 207, 2018.

[30] T. Islam, S. Attiq, Z. Hameed, N.K. Munnawar, and Sheikh, Z, "The impact of self-congruity (symbolic and functional) on the brand hate: A study based on self-congruity theory", British Food Journal, vol. 121 no.1, pp. 71-88, 2019.

[31] L. Zimerman, S. Shalvi, and Y. Bereby-Meyer, "Self-reported ethical risk-taking tendencies predict actual dishonesty" Judgment and Decision Making, vol. 9 no. 1, pp. 58-64, 2014. 